\title{
Mechanisms for Improving the Functioning of the Subjects of Housing and Communal Services in Russia
}

\author{
S. A. Shulepina ${ }^{1}$, V. V. Govdja ${ }^{2}$, G. V. Degaltseva ${ }^{2}$ \\ 1,2,3 Accounting department, Kuban State Agrarian University, Krasnodar, Russia. \\ Correspondence: Svetlana Shulepina, Accounting department, Kuban State Agrarian University, Krasnodar, Kalinina 13 \\ st., Russia.
}

Received: April 25, 2016

Accepted: May 19, 2016

Available online: May 24, 2016

doi:10.11114/aef.v3i3.1630

URL: http://dx.doi.org/10.11114/aef.v3i3.1630

\begin{abstract}
Today in Russia in conditions of the economic crisis, it is important to pay attention to summing up the reform of economic sectors with the most acute social orientation. One of these industries is the housing sector, including housing management. The research task is the needs to explore of housing sector reforming results and the prospects search of further development of house holding segment. To solve this problem statistical data for the past fifteen years has been used. It was considered the comparability of indicator prices for utility services in order to study the dynamics of its value in Russia and in 41 countries around the world from 1999 to 2011 in comparison to the index in the United States. The increase in this indicator in Russia explained the ongoing reform of the sector. And one of its most important aspects, as related to the transition housing and communal services to self-sufficiency and self-financing. Other indicators that characterize the current state of the sector housing and communal services are identifying in article by Russian regions: improving the living conditions of the citizens, slowdown in fees for public utilities. The modernization of the economy is impossible without a systematic approach to the development of a modern infrastructure of housing and communal services. One of the key aspects to enhance the functioning of control organizations, public utility considers improving their organizational structure. Improved model management and organizational structure of the managing organization and main business process are presented in the article.
\end{abstract}

Keywords: development, communal, management, business process, reforming

\section{Introduction}

An important aspect of the integration of Russia's economy in the global mechanism of market relations is the transition to self-sufficiency and self-financing of some national economy branches. In this regard, since 1999 in the framework of this direction, carried out reform of the sector of housing and communal services (HCS) - one of the key social sectors of the economy [2]. For Russia, the problem of housing and communal services is particular important due to the high level of wear and tear as the housing and engineering infrastructure, low quality of services provided. Reform of the housing sector as a special segment of services implies the need not only to finance the modernization of the public utilities and housing, but also the creation and efficient use of the mechanism of control and regulation [8]. Such approach to the problem allows identifying a number of factors that determine the relevance of the chosen topic.

First of all, it should be noted the insufficient development of the organizational and institutional basis of the industry regulation mechanism of housing and communal services in the current environment, which confirms the need to develop a theoretical and methodological basis of the management and regulation of the housing sector in the conditions of crisis in the Russian economy.

In addition, the conversion mechanisms of housing and communal services of state regulation methods and funding to market, economic-oriented methods of current economic conditions showed that the sharp reorientation processes in the industry did not produce a positive effect. This finding confirms the need for further improvement and development of the mechanism of management utilities.

An important aspect is the lack of a mechanism to monitor movement of utilities and financial resources at all levels of the public utility [1]. The factors mention above and as well as others, determine the research potential problems of formation and functioning of the economic mechanism of regulation of economic actors at different levels of public utilities regulation. These arguments for the relevance of the highlighted issues confirmed its importance. 
Among the works dedicated to the integrated management of housing and communal services, it is worth noting the work V. Zotov, C. Menard, V. Slinyakova, V. Chaikin, A. Shastiko. It should also highlight the work aimed at improving the management activities in organizations, including those of financial management. It works on the theory and practice of using the balanced scorecard (and its analogues), belonging to foreign scientists - R. Demeestre, P. Drucker, R. Kaplan, G. Kokinzu, J. Laverty, J. Little, D. Norton, J. Hoffecker, as well as local researchers - A. M. Borisov, M. S. Borisova, A. M. Gershuni, O.V. Nesmachniy.

Problems of improving the economic and institutional mechanisms for the control housing sector is deeply investigated in A. N. Asaul, OA Donicheva, I. Kuznetsova, Z. Chernyak, N. Yaskova et al.

The purpose of this paper is to solve the scientific problem of developing a mechanism to increase the efficiency of the subjects of housing and communal services in the conditions of its reforming through the optimization of governance organizations.

\section{Method}

To achieve this objective we have analyzed financial and economic aspects of housing reform. First of all, we considered the comparability of indicator prices for utility services in order to study the dynamics of its value in Russia and in 41 countries around the world from 1999 to 2011 in relation to the index in the United States [6].

\section{Results}

In 1999, the minimum value of a comparable level of prices for services HCS (4) observed in Russia and Ukraine. Behind them followed by Warsaw Pact countries and the republics of the CIS - up to 30. On the same level as the base country should Belgium, United Kingdom, Iceland, Australia, France, Israel, Sweden, Ireland, Luxembourg - range rate was from 90 to 110 points. The countries with the highest prices for housing and communal services are: Finland (111), Denmark (113), Germany (117), Switzerland (138), Japan (165).

By 2011, the minimum level of prices was registered in Ukraine, Russia moved to 2nd place. In former socialist countries figure increased significantly and amounted to more than 30 points. Is equivalent to US values were observed in the countries: Portugal, Greece, Austria, Israel. Japan managed to reduce the figure to 145 . The maximum comparable to US prices for housing services observed in the following countries: Norway (153), Denmark (174), Australia (188), Luxembourg (188), Switzerland (240). It is necessary to pay attention to the aspect of a significant increase in the cost of housing and communal services in Europe compared with the value of the index in the United States.

Table 1 provides a comparable level of prices for housing and communal services in dynamics for 13 years in a number of countries.

Table 1. Comparable prices for housing and communal services (US $=100), \% *$

\begin{tabular}{lcccccc}
\hline & \multicolumn{5}{c}{ Years } & $\begin{array}{c}\text { Deviation from the } \\
\text { 1999-2011, times }\end{array}$ \\
\cline { 2 - 6 } & 1999 & 2002 & 2005 & 2008 & 2011 & 1,2 \\
Austria & 89 & 67 & 90 & 120 & 107 & 1,7 \\
Bulgaria & 18 & 18 & 27 & 39 & 31 & 1,6 \\
Great Britain & 92 & 62 & 96 & 127 & 149 & 1,8 \\
Italy & 61 & 62 & 97 & 127 & 111 & 5,8 \\
Russia & 4 & 9 & 19 & 22 & 23 & 0 \\
USA & 100 & 100 & 100 & 100 & 100 & \\
\hline
\end{tabular}

* the data from the Federal State Statistics Service of the Russian Federation

In all the countries studied increased prices for housing and communal services when compared with the level of the most advanced economies of the world - the United States. At the same time in 1999 in presented in Table 1 countries, the level of prices for housing services was lower than in the United States. For example, in Bulgaria - more than 5 times, and in Russia - 25 times.

A similar situation will continue in 2005. Namely the level of prices has been increased, but the value remains below the base of the country. Since 2008, due to a significant increase in price for housing and communal services, their cost in Austria, Great Britain, Italy, exceeded the price level in the United States. By 2011, the comparable price has increased significantly in Bulgaria by 1.7 times, Britain - in 1,6 times, in Italy - by 1.8 times. The largest price increase 
occurred in Russia - almost 6 times.

The increase in this indicator in Russia explained the ongoing reform of the sector. And one of its most important aspects, as related to the transition housing and communal services to self-sufficiency and self-financing.

It should identify other indicators that characterize the current state of the sector housing and communal services:

- Improving the living conditions of the citizens;

- Slowdown in fees for public utilities.

Let us consider these parameters.

Moving the industry of housing and communal economy to self-sufficiency is an important aspect for the development of market relations in this segment of the market. The ability to reduce the dependence of the functioning of the economic agents of the state and local government subsidies can improve the investment attractiveness of the industry.

In general, in the Russian Federation during the study period (from 2010 to first half 2015), the level of reimbursement population rose from $90.1 \%$ to $92.5 \%$ (Table 2).

Table 2. The level of compensation for the costs of providing public utility services, $\% *$

\begin{tabular}{|c|c|c|c|c|c|c|}
\hline \multirow{4}{*}{ Region } & \multicolumn{6}{|c|}{ Years } \\
\hline & & & & & & 6 month \\
\hline & 2010 & 2011 & 2012 & 2013 & 2014 & of the \\
\hline & & & & & & 2015 \\
\hline Russian Federation, total & 90,1 & 89,7 & 89,9 & 89,8 & 90,7 & 92,5 \\
\hline Southern Federal District, including & 97,0 & 96,9 & 99,7 & 99,7 & 99,7 & 99,5 \\
\hline Adygea Republic & 100,0 & 100,0 & 100,0 & 100 & 100,0 & 100,0 \\
\hline Kalmykia Republic & 89,2 & 96,1 & 94,2 & 95,9 & 97,5 & 92,4 \\
\hline Krasnodar region & 100,0 & 100,0 & 100,0 & 100 & 100,0 & 100,0 \\
\hline Astrakhan region & 99,4 & 99,6 & 99,6 & 99,5 & 99,8 & 99,6 \\
\hline Volgograd region & 93,2 & 86,5 & 99,3 & 99,3 & 99 & 98,5 \\
\hline Rostov region & 95,9 & 99,3 & 99,8 & 99,9 & 99,9 & 99,9 \\
\hline
\end{tabular}

* the data from the Federal State Statistics Service of the Russian Federation

For comparison, in 2000, the initial stage of implementation of the tasks of reforming the housing and utilities sector, the figure was $53.0 \%$ on average in Russia. It should be noted that the level of reimbursement population, calculated in the context of the Southern Federal District is much higher nationwide values, indicating a higher level of independence of economic actors in the region on state funding.

Among the subjects of the Southern Federal District Republic of Adygea is necessary to allocate or Krasnodar region, where the level of cost recovery of a population of $100.0 \%$.

When considering the industry reform housing and communal services we considered the share of spending on housing and communal services in the general set of ongoing costs (Table 3). It should be noted a significant increase in the expenditures on housing and communal services in all regions except the Krasnodar region, where there is a decline at the end of the study period. The greatest changes in the share of expenditures observed in the Republic of Kalmykia (2.2 times) and the Astrakhan region (2.5 times). 
Table 3. Share of spending on housing and communal service in the total population implemented cost, $\% *$

\begin{tabular}{|c|c|c|c|c|c|}
\hline \multirow{2}{*}{ Region } & \multicolumn{4}{|c|}{ Years } & \multirow{2}{*}{$\begin{array}{c}\text { Deviation from } \\
\text { the } 2011,1999, \\
\text { time }\end{array}$} \\
\hline & 1999-2002 & $2003-2006$ & $2007-2010$ & 2011-2014 & \\
\hline Russian Federation, total & 5,2 & 8,0 & 8,5 & 9,8 & 1,9 \\
\hline $\begin{array}{l}\text { Southern Federal District, } \\
\text { including }\end{array}$ & 5,6 & 8,1 & 8,5 & 10,1 & 1,8 \\
\hline Adygea Republic & 5,1 & 7,8 & 8,9 & 7,6 & 1,5 \\
\hline Kalmykia Republic & 5,1 & 6,8 & 6,7 & 11,2 & 2,2 \\
\hline Krasnodar region & 6,8 & 8,5 & 8,3 & 6,3 & $\mathbf{0 , 9}$ \\
\hline Astrakhan region & 4,2 & 6,4 & 6,2 & 10,3 & 2,5 \\
\hline Volgograd region & 6,7 & 9,1 & 9,8 & 11,0 & 1,6 \\
\hline Rostov region & 5,6 & 9,3 & 9,9 & 9,2 & 1,6 \\
\hline
\end{tabular}

* the data from the Federal State Statistics Service of the Russian Federation

Consider the dynamics of change in the above figure schematically in Figure 1.

During the study period from 1999 to 2014, the share of expenditure on housing and communal services increased in all regions. The exception was the Krasnodar region, where the figure fell by $0.5 \%$. The reason for increasing the share index of the cost of housing and communal services in the total value of household spending may be rising cost of housing and communal services at a faster pace than income growth.

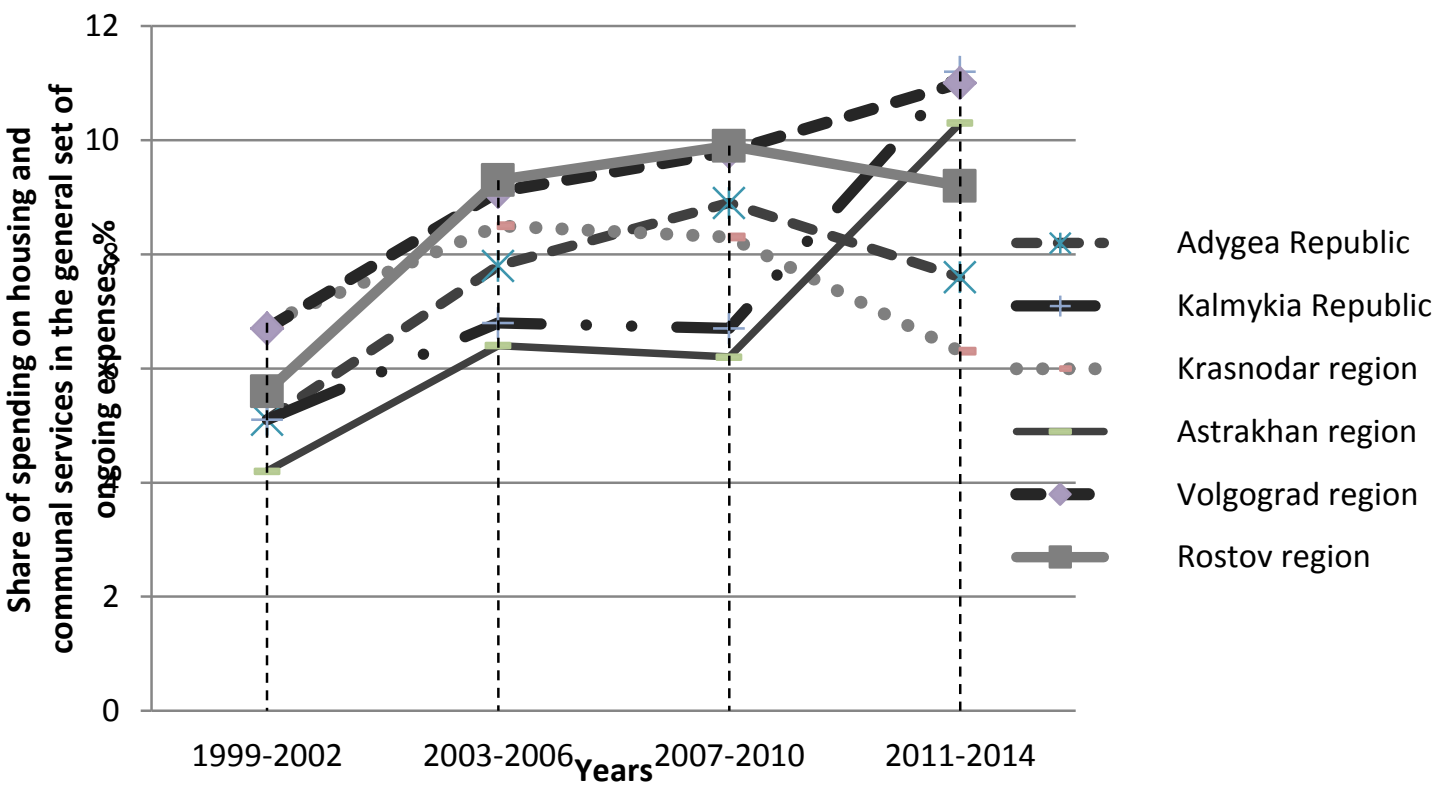

Figure 1. Changes in the share of expenditure on housing and communal services in the total value of household spending in Russia

To confirm or refute this result it is necessary to consider the size of utility services cost per person and per month (Table 4).

First of all, it is worth noting that the rate of the cost of housing and communal services in Russia in general higher than the average for the SFD by about $30-40 \%$.

The highest growth rate of the cost of utility services per person per month is observed in the Astrakhan region - 78.6\%. In the same subject and was the largest increase in the share of expenditure on housing and communal services - by 6.1 point.

At the same time, despite the increase in the cost of the fee for housing and communal services for one person is $40 \%$, the share of expenditure in the general budget of households has been declined. This indicates a different level of 
economic development of regions and subjects.

These special surveys of management companies Defense of Krasnodar and the Krasnodar Territory suggest that the overall situation of reform adopted by the industry is gradually being implemented [5]. However, consumers constantly complain HUS in the institutional authorities on the rapid growth of tariffs, low quality of services provided in the substantial absence of liability (off water, electricity, garbage hauling, cleaning house territory, and etc.) A particularly heavy burden is reflected in the life of the elderly and low-income families.

Table 4. Cost of housing and communal services for 1 person per month, rub. *

\begin{tabular}{|c|c|c|c|c|c|c|c|}
\hline \multirow{2}{*}{ Region } & \multicolumn{6}{|c|}{ Years } & \multirow{2}{*}{$\begin{array}{c}\text { Rate of } \\
\text { increase } \\
\%\end{array}$} \\
\hline & 2009 & 2010 & 2011 & 2012 & 2013 & 2014 & \\
\hline $\begin{array}{l}\text { Russian Federation, } \\
\text { total }\end{array}$ & 1361,04 & 1528,69 & 1710,15 & 1788,87 & 1968,58 & 2093,51 & 53,8 \\
\hline $\begin{array}{l}\text { Southern Federal } \\
\text { District, including }\end{array}$ & 1047,81 & 1110,79 & 1277,07 & 1294,79 & 1376,9 & 1485,3 & 41,8 \\
\hline Adygea Republic & 951,58 & 1065,53 & 1239,03 & 1200,9 & 1407,78 & 1527,68 & 60,5 \\
\hline Kalmykia Republic & 824,08 & 883,96 & 982,32 & 1007,32 & 1173,57 & 1368,33 & 66,0 \\
\hline Krasnodar region & 1016,35 & 971,71 & 1163,5 & 1195,34 & 1308,73 & 1474,14 & 45,0 \\
\hline Astrakhan region & 1002,07 & 1208,95 & 1448,33 & 1254,78 & 1446,3 & 1789,26 & 78,6 \\
\hline Volgograd region & 1117,88 & 1254,21 & 1474,4 & 1447,92 & 1480,29 & 1556,4 & 39,2 \\
\hline Rostov region & 1083,96 & 1207,38 & 1351,93 & 1409,45 & 1454,33 & 1501,98 & 38,6 \\
\hline
\end{tabular}

* the data from the Federal State Statistics Service of the Russian Federation

It should be noted, however, that many of the residents of apartment buildings just do not pay utility bills, do not install water, heat meters and so on. N., Remain indifferent in the landscaping of their landings, house territory. The administration of management companies is also restricted in the right to punish dodgers' services. This leads to a violation of the payment discipline of management companies and providing organizations.

Therefore, the modernization of the economy is impossible without a systematic approach to the development of a modern infrastructure of housing and communal services [4]. This requires the adoption of measures to improve the efficiency of the housing stock, the modernization of municipal infrastructure, improve the quality and reliability of delivery of municipal resources, introduction of modern technologies and training of qualified managers.

One of the key aspects to enhance the functioning of control organizations, public utility consider improving their organizational structure [3]. Using outdated control mechanisms leads to a lack of ways of development of the economic entity and the loss of market segment in the future.

The management organization responsibilities need to build so that the responsible persons have been authorized to make decisions and be responsible for the results of all related projects and processes rather than on their parts [8]. During cross-functional and cross-cutting projects and processes necessary to assign responsibility to a specific person (a collegial body), which has the appropriate resources and powers. This approach will reduce the cost of implementation of projects and processes by eliminating probable losses incurred due to lack of coordination of participants, as the struggle between them for status, influence or resources.

The size and composition of the units must comply with the specific objectives of the economic entity, based on the available resources. Today, staffing and organizational structure of the Russian management companies, to a lesser extent depend on the tactical and strategic objectives. In modern conditions, the unpredictability of the market situation existing staffing and organizational structures are ballast. It should be noted that the drastic downsizing that has occurred in many Russian organizations today, led to a decline in the quality and speed of the remaining workers. In this regard, of particular relevance are the creation of an organizational structure of the organization, when lack of "extra" underperforming employees, departments duplicating the work of other.

To achieve the above objectives, it is first necessary to allocate the basic business processes of the organization that is creating divisions. In our view, every unit must comply with specific processes and participate in the implementation of cross-cutting. To do this, we need to describe the business model of the economic subject, identify the main chain of processes (Figure 2). 


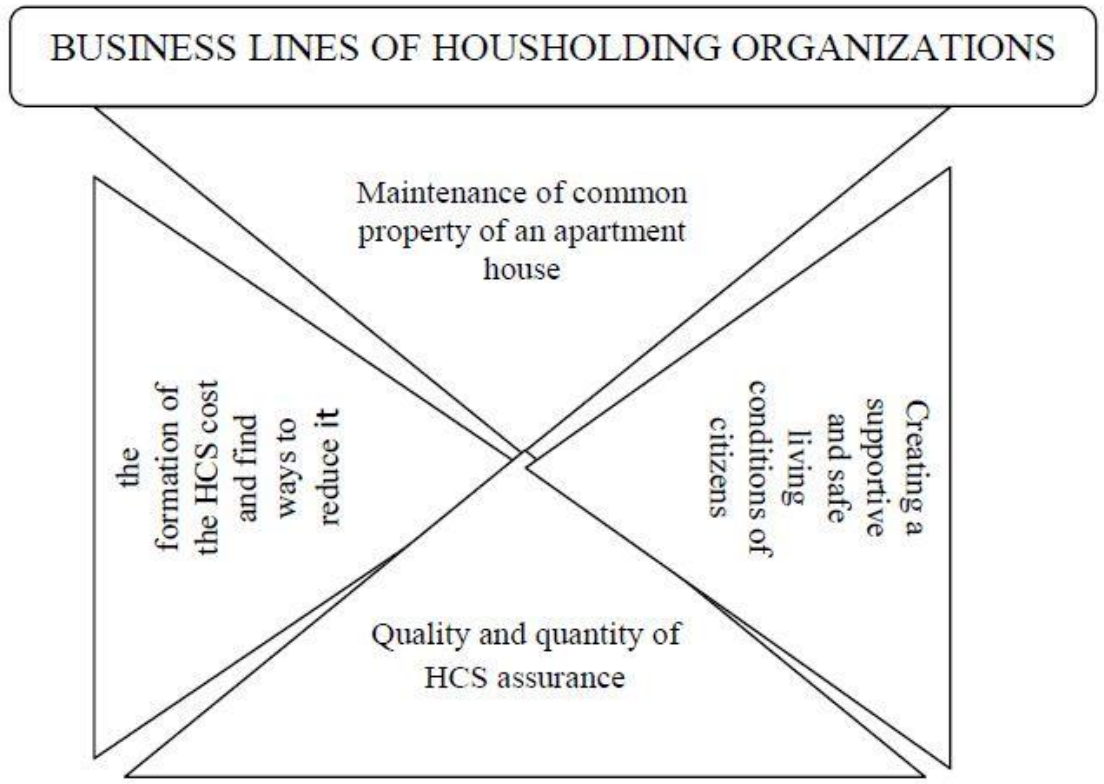

Figure 2. The main business line of house holding organization

Based on selected business areas we were classified business processes management organizations (Figure 3): the basis, support, and business process management.

Performing basic processes carried out within the engineering unit, settlement and passport service. Supporting processes are the responsibility of the financial, economic, legal departments, and supply departments. It should be noted that today business-management processes are carried out directly without administration management organization responsible allocation of units and individuals within it.

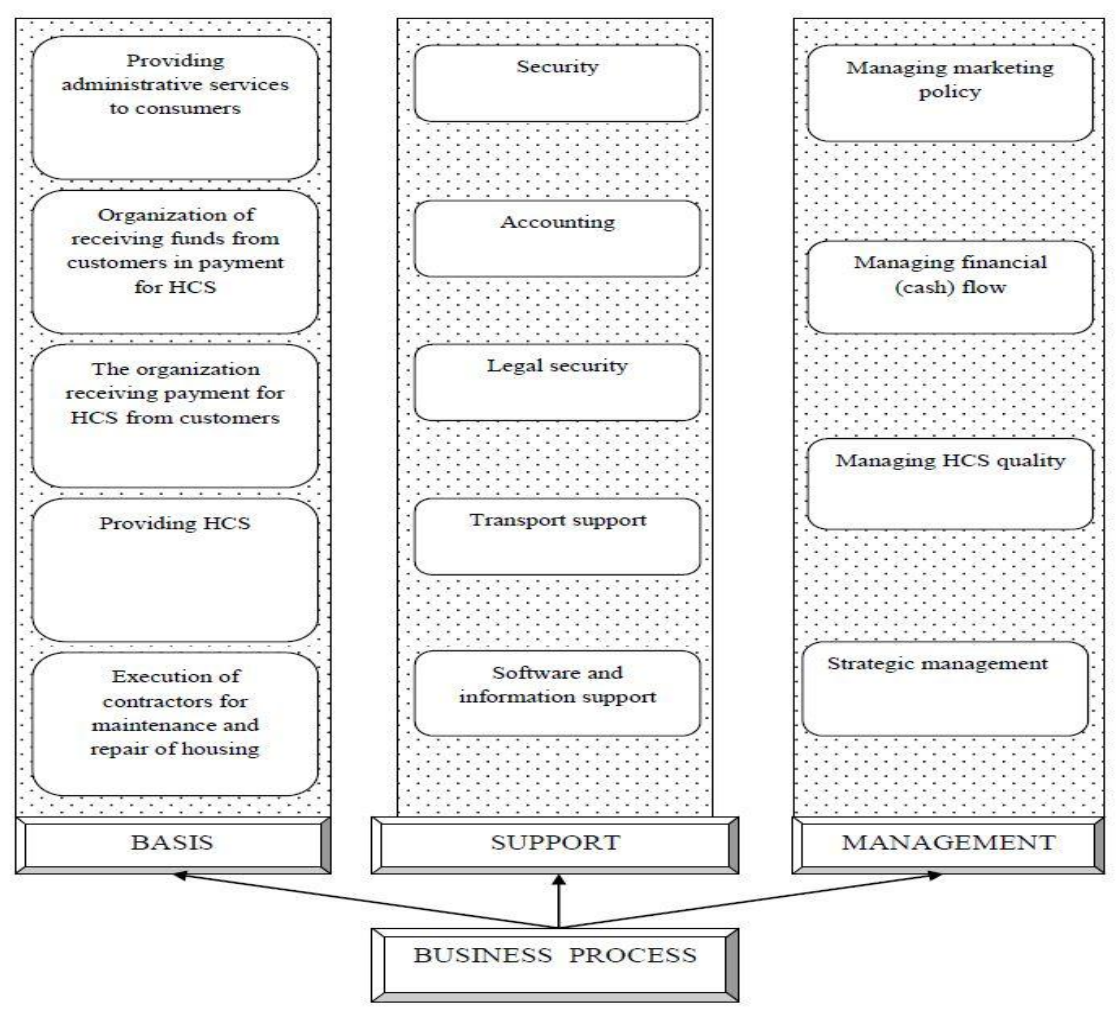

Figure 3. Householding organization business processes

To optimize the management and organizational structure of the study subjects and their compliance with business processes, we proposed to implement the activities of housing companies' new departments (figure 4):

1. The marketing department, whose main task will be to investigate the market housing, making the information 
provided about housing services and their prices to consumers and other market entities submitting proposals for the development of the market value-added services based on the needs of the population;

2. PR-department, aiming at creating a positive image among consumers of the managing organization of housing and communal services, as well as acting as a representative of the organization of public relations;

3. The internal control quality utility services - is necessary for the additional security of living conditions of citizens, monitoring of the actual performance of work on maintenance and current repairs of housing stock, as well as the characteristics of public services.

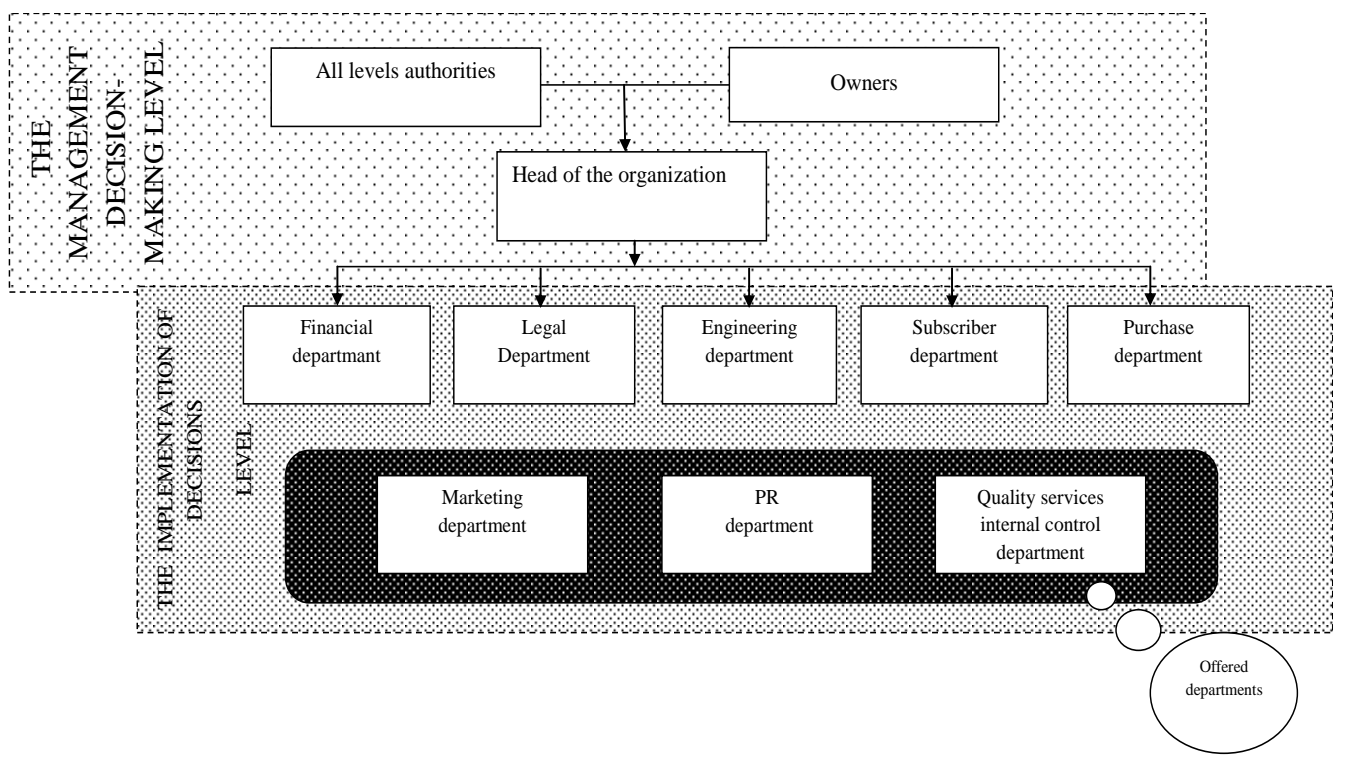

Figure 4. Improved model management and organizational structure of the managing organization

In addition, the offer to amend the operation of existing services and departments managing organizations:

1. Select the individual areas of operation of the legal service: department of the municipal and housing organizations on the issues of debt and the quality of services and the department to work with the consumers of utility services - to address the timeliness of payment, as well as incoming claims from the public. At the level of the Russian State Duma to pass a law on the levying of penalties for late payment for utility services. Give bailiffs the right to charge indisputably funds or property of citizens, non-payers.

2. In a separate entity to allocate cash-service passport without submitting financial service.

After all, the construction of an optimal system of managing organization is important to consider the actual participation in decision-making bodies at all levels. This participation is reflected in the publication of legal acts, the presence of control activity by the supervisory bodies, etc.

Based on the mentioned above it can be concluded that the existing practice management tools are ineffective and need revision. Our proposed model of building organizational and management structure of the management organization will reduce the period of time from the date of the administrative decision to implement it, to allocate those responsible (responsible units) for a particular business process, and thus lead to lower costs of the organization as a whole. This new administration has objective ultimately improve quality control utilities, on the one hand, and to reduce the cost of administrative services on the other.

\section{References}

Buzdugan, A. (2013). Ways to Optimize the Labourin the Communal Housing Complex. Economie Si Sociologie: Revista Teoretico-Stiintifica. Institutul National De Cercetari Economice, 169-178

Shulepina, S. A. (2015). The state and development of housing and communal sector of Russia, Eurasian journal of economic and finance, 3(3), 65-71. http://dx.doi.org/10.15604/ejef.2015.03.03.006

Chevallier, J. (2012). Le service public. Paris: PUF.

State Corporation - Fund of Housing and Utilities Reform (2015). Key performance indicators of the state corporation Reform Fund Housing and Communal Services in 2014. Retrieved from http://fondgkh.ru/ result/result/ pokazat/183357.html

Ministry of fuel and energy complex and housing and utilities infrastructure of Krasnodar Region (2015). The road map 
of Krasnodar Region HCS.

http://gkh-kuban.ru/_files/dor_karta_gkh/postanovlenie_gakk_26122014_1564.pdf

Federal State Statistics Service. (2015). United interagency informational - statistical system. Retrieved from http://www.fedstat.ru/indicators/start.do

Men, M. (2015). Russian HCS: new conditions for the public-private partnerships development. Retrieved from http://www.minstroyrf.ru/press/vystupleniya-ministra-mikhaila-menya-na-panelnoy-sessii-zhkkh-rossii-novye-uslo viya-razvitiya-gosuda/

State Corporation - Fund of Housing and Utilities Reform. (2015). Analytics of houses capital repairs. Retrieved from https://www.reformagkh.ru/overhaul/analytic/ \#overhaul_collection_of_owners/

\section{(cc) EY}

This work is licensed under a Creative Commons Attribution 3.0 License. 